\title{
Diários de Maria Isabel Silveira: vestígio e inscrição de uma voz
}

\author{
[Diaries of Maria Isabel Silveira: trace and inscription of a voice
}

\section{Mariana Diniz Mendes ${ }^{\mathrm{I}}$}

Agradeço ao meu orientador, professor Marcos Antonio de Moraes, por propiciar meu encontro com os diários de Maria Isabel Silveira e pela atenção, precisão e generosidade com que vem me guiando. Agradeço a Elisabete Marins Ribas, Bete querida, pelo tanto que me ensina sobre o maravilhoso mundo dos arquivos pessoais. E, por último, meu agradecimento a Carolina Pulici, pela amizade e diálogo constante.

RESUMO • Este artigo aborda o conjunto de diários pertencentes a Maria Isabel Silveira, casada com o escritor e político Valdomiro Silveira, cujo acervo pessoal foi doado ao IEB/USP em 2006. Em meio aos documentos, atualmente sob a guarda da instituição, destacase o conjunto de 62 cadernos que pertenceram a Maria Isabel, entre os quais os volumes que acolheram a sua escrita diarística como registro do cotidiano de sua família, especialmente de seus filhos e, posteriormente, de seu dia a dia. O presente estudo versa sobre materialidade documental, escrita feminina e memória das mulheres, tendo como corpus os diários de Maria Isabel, uma mulher que, com rigor e disciplina, escreveu sobre si e, consequentemente, sobre sua época. • PALAVRAS-CHAVE • Diário; memória; narrativas; Maria Isabel Silveira; história das mulheres; escrita feminina. · ABSTRACT - This article presents the investigation made from the set of diaries belonging to Maria Isabel Silveira, wife of the writer Valdomiro Silveira, whose personal collection was donated to the IEB/USP in 2006. Amid the documents, currently under the custody of the IEB Archive, stands out 62 notebooks by Maria Isabel that adopts diary writing as a record of her family's daily life, especially her children, and later, of her daily life. The present study deals with documentary materiality, feminine writing and women's memory, having as corpus the diaries of Maria Isabel, a woman who with rigor and discipline, wrote about herself, and, consequently, about her time. - KEYWORDS - Diary; memory; narratives; Maria Isabel Silveira; women's history; feminine writing.

Recebido em 15 de setembro de 2020

Aprovado em 26 de outubro de 2020

MENDES, Mariana Diniz. Diários de Maria Isabel Silveira: vestígio e inscrição de uma voz. Revista do Instituto de Estudos Brasileiros, Brasil, n. 77, p. 220-250, dez. 2020.

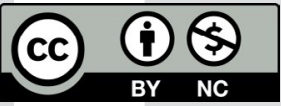

DOI: https://doi.org/Io.II6o6/issn.23I6-90IX.vii77p220-250

I Universidade de São Paulo (USP, São Paulo, SP, Brasil). 
O diário é a âncora que raspa o fundo do cotidiano e se agarra às asperezas da vaidade. (BLANCHOT, 2005, p. 273).

Escrever é viver mais. (André Comte-Sponville, I997, p. 37).

Enxergar o passado das mulheres com clareza é um desafio das pesquisas acadêmicas uma vez que elas estiveram mergulhadas em silêncios impostos, anulando a importância de suas próprias histórias. Em uma sociedade com tantas desigualdades e discriminações também evidenciadas nas questões de gênero, muito se ganha ao fazer emergir novos objetos, como diários, que suprem uma lacuna historiográfica. Tendo isso em vista, as próximas páginas se dedicarão a apresentar os diários de Maria Isabel como fonte privilegiada de investigação.

Em agosto de 2006, o Instituto de Estudos Brasileiros da Universidade de São Paulo (IEB/USP) recebeu o acervo pessoal de Valdomiro Silveira (I873-I94I). Documentos, livros, manuscritos, cartas e fotografias foram doados por Isabel Leal Góes e Ana Maria Leal Góes de Mello, neta e bisneta do autor paulista. Segundo de oito filhos do jurista João Baptista da Silveira e Cristina Alzamora da Silveira, sua biografia é extensa e multifacetada: advogado formado nas arcadas do Largo São Francisco, herdou do pai não apenas a profissão, como também a paixão pelas letras. Além da advocacia, do jornalismo e da literatura, esteve à frente de cargos políticos secretário da Educação do Estado de São Paulo, deputado estadual pelo mesmo estado e vice-presidente da Constituinte Paulista. Como escritor, Valdomiro se dedicou a pesquisar o universo caipira. Seus principais livros são: Os caboclos (I920), Nas serras e nas furnas (I93I), Mixuangos (I937) e Leréias (póstumo). 


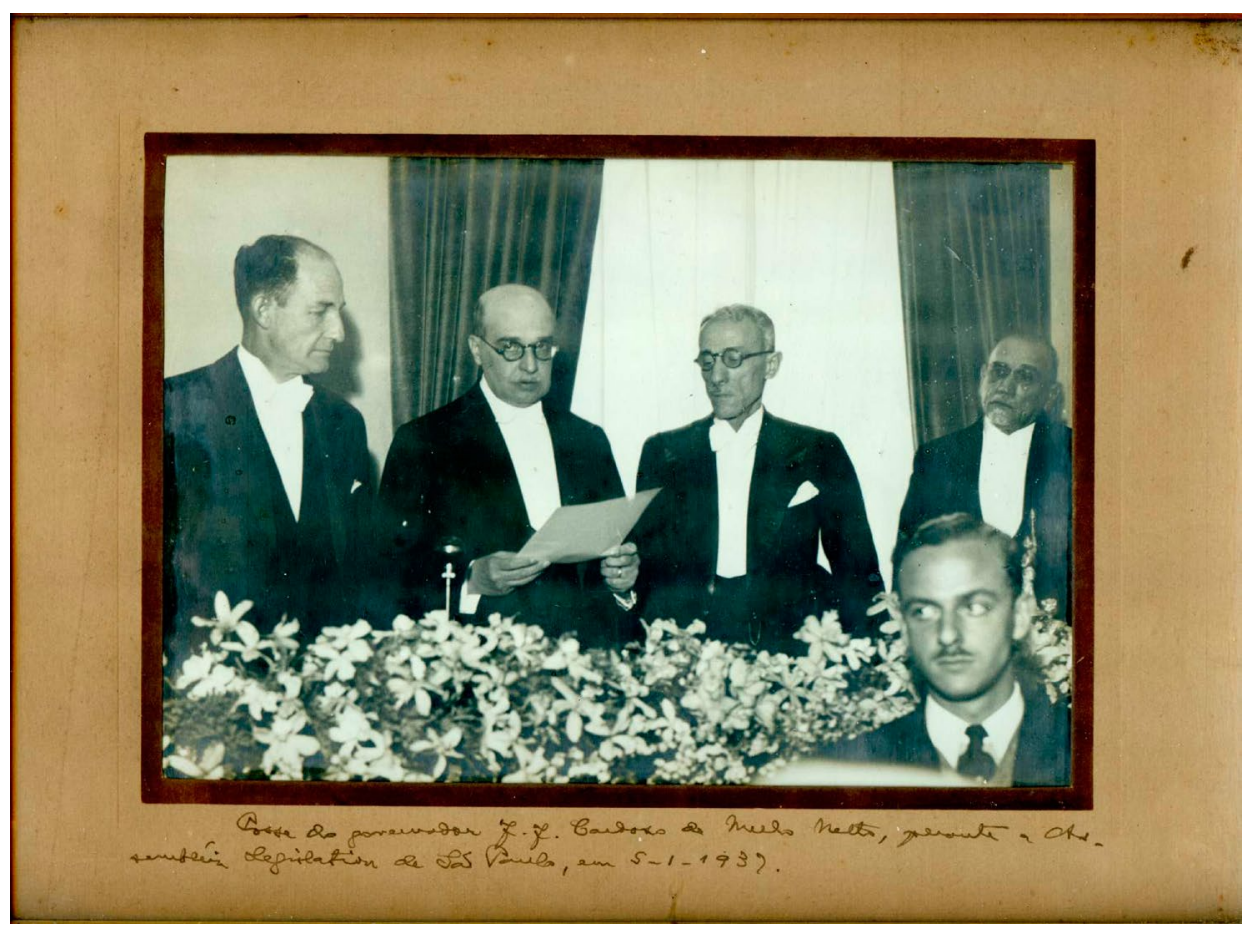

Figura I - Valdomiro Silveira, ao centro, à direita de José Joaquim Cardoso de Melo Neto, empossado governador de São Paulo em I937.

Arquivo IEB/USP, Fundo Valdomiro Silveira, código de referência VS-F-oI7

Em meio aos documentos de Valdomiro Silveira, destaca-se um conjunto de cadernos de Maria Isabel Silveira (I880-I965), casada com o escritor. Neles, ouve-se a voz de uma mulher que tomou para si o projeto de registrar seu dia a dia regularmente, durante anos de sua vida longeva. Ao todo 62 diários se misturam ao volumoso material do marido. No parecer que documenta a doação, a professora Telê Ancona Lopez registra: "Agregado a esse conjunto, o diário de Isabel Silveira surge como um documento relevante na esfera da história do cotidiano”2. Dos cadernos, 54 pertenceram a Isabel e percorrem 57 dos 85 anos vividos. Como escritora, Isabel publicou artigos humorísticos na imprensa sob o pseudônimo de "Baronesa de Itororó” e o livro de memórias Isabel quis Valdomiro, em I962, pela editora Francisco Alves, que narra a história de seu casamento e da vida ao lado do marido.

2 Memorando (MEMO.Dir/oog/IEB/I8.08.2006) de doação, presente no processo USP número: 2006.I.I82.3I.9. 


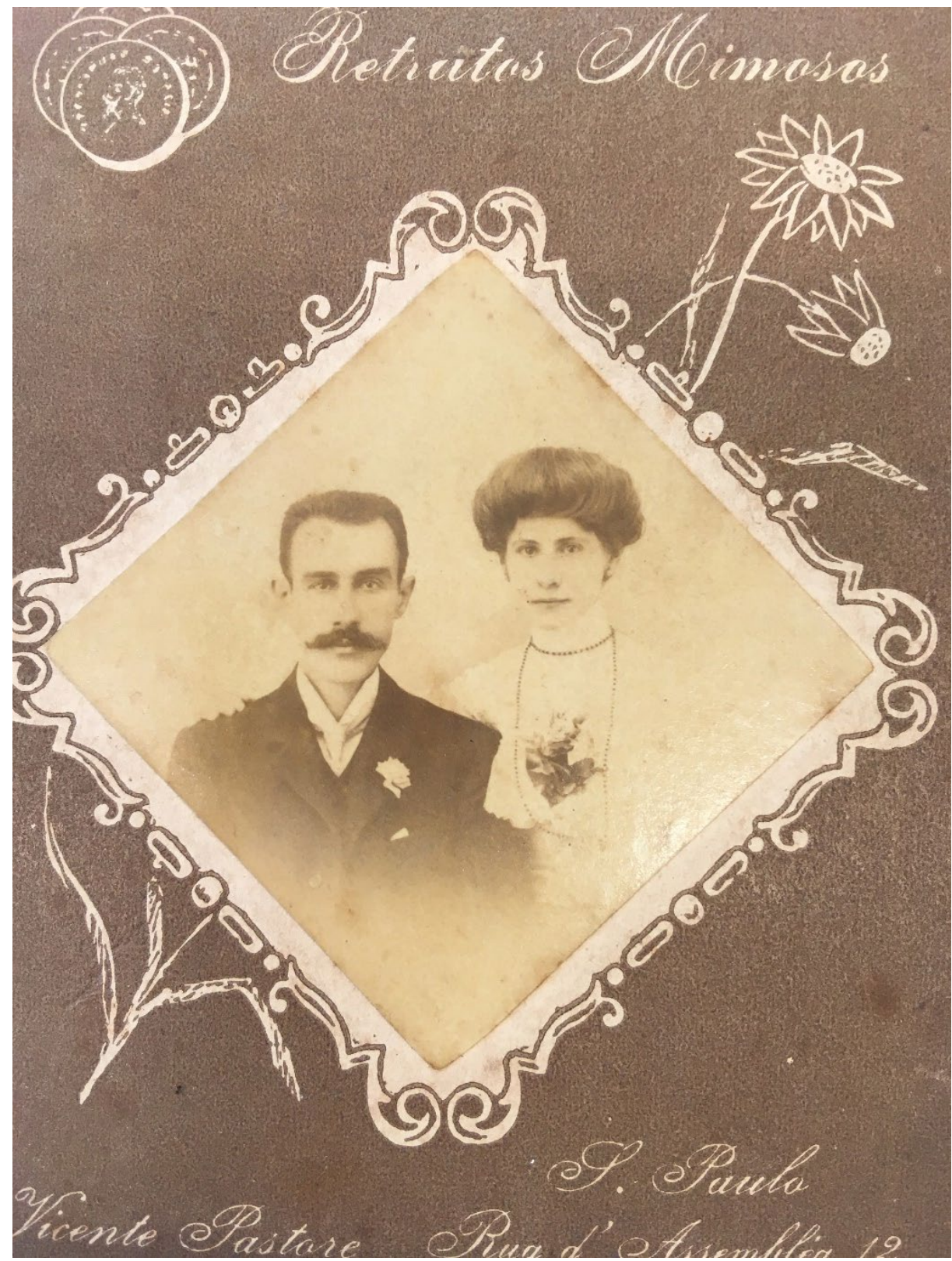

Figura 2 - Retrato do casal, I904. Arquivo IEB/USP, Fundo

Valdomiro Silveira, código de referência VS-F-ooI 


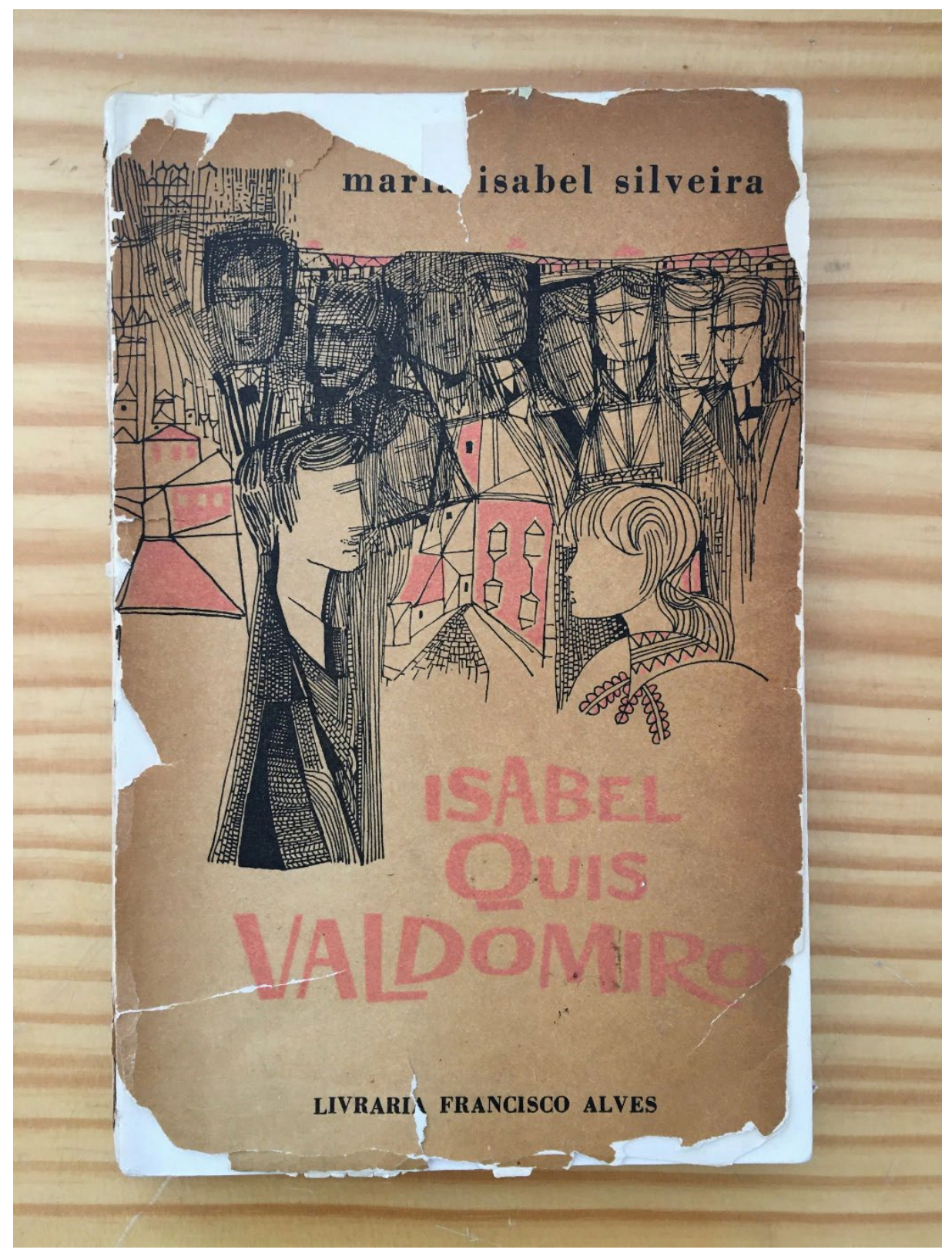

Figura 3 - Capa do livro publicado em I962

O vultoso número de páginas, linhas e palavras manuscritas revela o gosto de Maria Isabel pela escrita. O diário mais antigo encontrado no acervo exibe, no registro inaugural, a data 24 de dezembro de I908; a última entrada do último diário foi produzida em I2 de junho de I965, apenas dois meses e sete dias antes de morrer. Na apresentação de seu livro de memórias, Isabel refere-se aos diários: “Esse trabalho, que seria difícil se o quisesse realizar apenas com o auxílio da memória, 
foi-me facilitado pelos 'diários' que escrevi na ocasião em que meus cinco filhos eram pequenos” (SILVEIRA, I962, p. 8).

Em uma passagem sobre a visita de Rui Barbosa à sua casa, é perceptível o orgulho que sentia e o valor que a memorialista concedia à prática:

Recebi-os também em nossa casa [Rui Barbosa e sua esposa dona Marianinha], onde lhes ofereci um chá e lhes apresentei nossos quatro filhos. Gostaram muito deles. Quando lhes contei que fazia o "diário!" de todos, um por um, Rui comentou com aquela excelsa bondade que o caracterizava:

- Basta isso para definir seu caráter, dona Isabel. (SILVEIRA, I962, p. I43).

Valdomiro e Isabel casam-se em I905, em São Paulo, viajam para a lua de mel em Santos, onde vivem por 36 anos, até a morte dele, em I94I. O casal e os cinco filhos - Junia (I906), Valdo (I907), Isa (I9I0), Belkiss (I9I2) e Miroel (I9I4) - passam boa parte de suas vidas em sua residência na rua Conselheiro Nébias, 8I6. A casa recebia com regularidade alguns dos escritores e poetas daquele tempo: Monteiro Lobato, Martins Fontes, Claudio de Souza, Ricardo Gonçalves, Vicente de Carvalho, Francisco Escobar, além de políticos, como Rui Barbosa, por exemplo. Em Santos, Isabel iniciará a escrita de seus inúmeros diários. Nota-se a linhagem intelectual da família: Maria da Glória Quartim (memorialista), Yone Quartim de Moraes (escritora), Alarico Silveira (jornalista), Dinah Silveira de Queiroz (romancista), Helena Silveira (cronista), Isa Silveira Leal (escritora e tradutora), Breno Silveira (jornalista), Miroel Silveira (escritor, diretor e crítico de teatro), Ênio Silveira (editor) e Belkiss Silveira Barbuy (filósofa) - todos nomes de destaque da época em que viveram. 


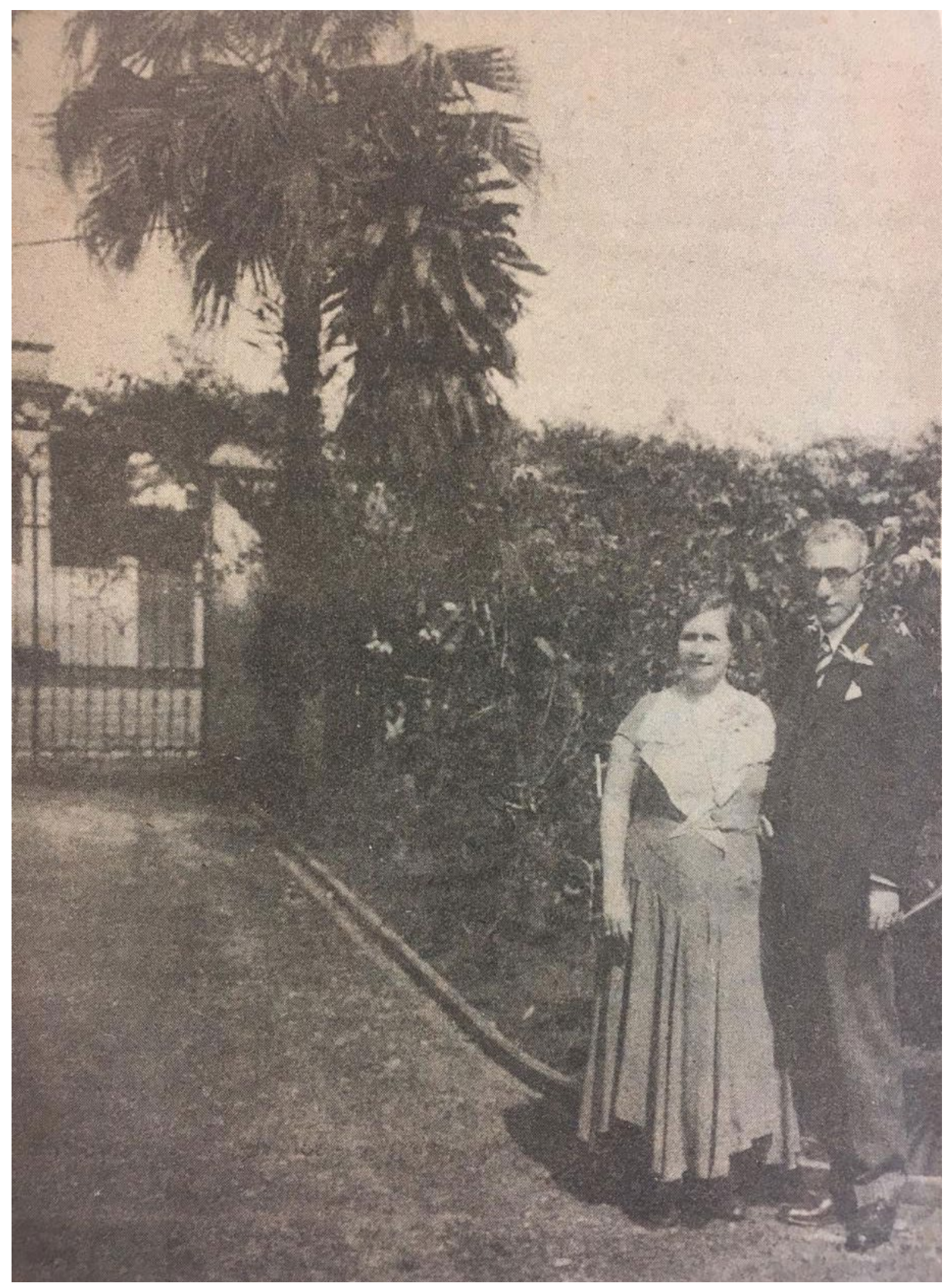

Figura 4 - Isabel e Valdomiro. Arquivo IEB/USP, Fundo Valdomiro da Silveira, código de referência VS-F-oo2 


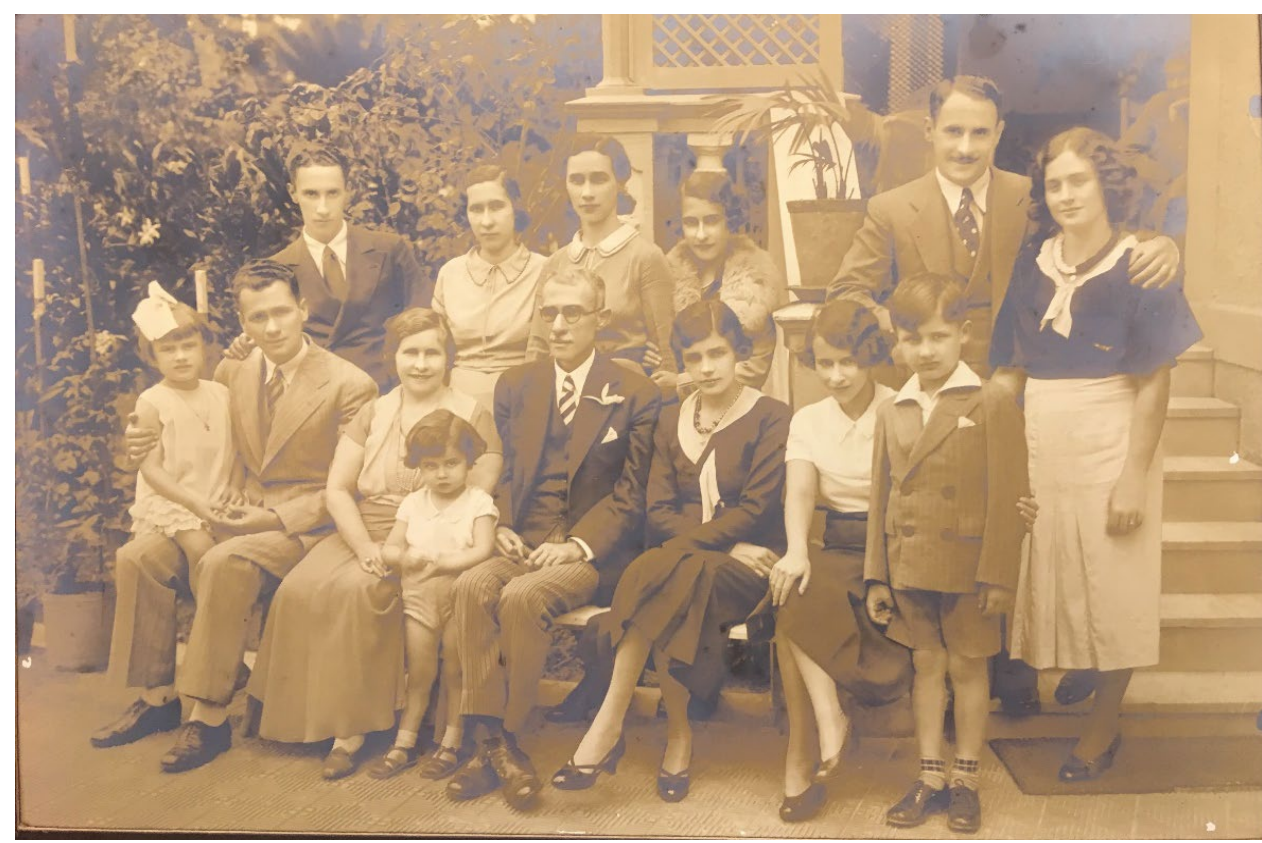

Figura 5 - O casal em foto de família. Arquivo IEB/USP, Fundo

Valdomiro da Silveira, código de referência VS-F-003

Os diários de Maria Isabel estão na contramão do diagnóstico mapeado pelas pesquisas acadêmicas que problematizam o escasso material documental (fontes historiográficas e sociológicas) sobre a mulher brasileira. O número 7I da Revista do Instituto de Estudos Brasileiros, organizado pelas professoras Ana Paula Simioni e Maria de Lourdes Eleutério, apresenta um rico dossiê para abordar duas questões interligadas: “I) a precariedade de fontes disponíveis para se reconstituir uma história das mulheres; 2) as complexas relações históricas e sociais que envolvem o reconhecimento da autoria feminina" (SIMIONI; ELEUTÉRIO, 20I8, p. 20). Se os diários de Maria Isabel representam uma exceção nesse contexto pelo fato de seu marido ser figura importante na área literária, surge então uma pergunta automática: quanto do que as mulheres escreveram não terá se perdido? Em seu livro Álbum de leitura, Lilian de Lacerda traça o percurso de leitura e escrita de mulheres memorialistas investigando as práticas que cercavam essas atividades entre meados do século XIX e o início do século XX:

Muitas das autoras não tinham intenção prévia de publicação, visto que, como afirmou Cecília Assis Brasil, a prática da escrita fazia parte de uma rotina de moças que guardavam em seus cadernos amores secretos. Se esse era o propósito, ou um dos propósitos da escrita íntima feminina, seu fim acabava sendo a fogueira, uma vez que os cadernos escondiam mistérios, sentimentos e desejos proibidos pela moral que regia a moça de boa família. (LACERDA, 2003, p. 50). 
No âmbito da arquivística, um documento é arquivado por ser considerado importante para a memória, o que torna os arquivos de instituições, públicas ou privadas, intrinsecamente relacionados às esferas de poder. São lugares de legitimação da cultura dominante. A escrita de mulheres representa uma pequena parcela dentro dos arquivos brasileiros. Se as mulheres escreveram muito, esses textos se perderam, e se não aparecem é de se supor que refletem o silêncio e o silenciamento historicamente impostos às mulheres. A questão demonstra o caráter interdisciplinar do presente estudo em curso por mobilizar um diálogo com diversos saberes - gênero, literatura, arquivística e história social. A abundância de cadernos denota a importância de delimitar a pesquisa, por isso este artigo expõe a gênese da escrita a partir dos dez diários mais antigos encontrados no acervo - "diários dos filhos” e do Diário I, do ano de I925, quando Isabel se concentra exclusivamente em escrever sobre si.

\section{Maria da Glória Quartim de Moraes: "Não SOU UMA MULHER, SOU UMA PEDRADA!”3}

Da mesma maneira que é preciso apresentar Valdomiro para chegar aos diários, a mãe de Isabel, Maria da Glória Quartim de Moraes (I850-I937), é a segunda figura incontornável para compreender a importância da escrita na vida da filha. Dos 62 cadernos que compõem o Fundo Valdomiro Silveira, oito não são de Isabel. Seis são de Maria da Glória, carinhosamente conhecida como D. Maricota 4 . A miscelânea de cadernos da mãe misturados aos da filha evidencia a prática da escrita como parte importante da cultura familiar. Convoco Isabel para apresentar a figura marcante de Maria da Glória:

Minha mãe, Maria da Gloria (só a chamavam de Maricota), era uma criatura de forte personalidade, originalíssima. Meus filhos não têm a puxar cabeça apenas do lado Silveira, pois também minha velha, nascida numa época em que se negava à mulher até o direito de aprender a ler e a escrever, soubera abrir seu caminho lendo, investigando, convivendo com homens de cultura. Sua roda não se compunha de comadres idiotas, e sim das mais sólidas culturas do seu tempo: o Brigadeiro Machado de Oliveira, Pedro Taques, Padre Valadão, Emilio Vautier, Manoel Dias de Toledo Júnior, Américo de Campos, dom Manoel do Vale, Dr. Vicente Cabral, Huascar Vergara, Luís Gama, Crispiniano Soares, Angelo Agostini, Joaquim Augusto e Júlia Azevedo e tantos outros. Como tantos espíritos de seu tempo sofrera influência voltairiana, e tendia para o materialismo e a sátira. Muitos anos mais tarde, porém, quando perdeu meu mano Carlos, barbaramente assassinado em Bauru, passou por uma crise religiosa e converteu-se ao espiritismo, em cuja crença morreu aos 86 anos de idade, no ano de I937. (SILVEIRA, I962, p. I6I).

3 Conforme está registrado em Reminiscências de uma velha (MORAES, [I98I], p.9).

4 Dois são atribuídos a Isabel (a neta que assinou a doação do acervo ao IEB/USP) e um último, a Júnia, a primogênita do casal, com a finalidade de contar a história da família 


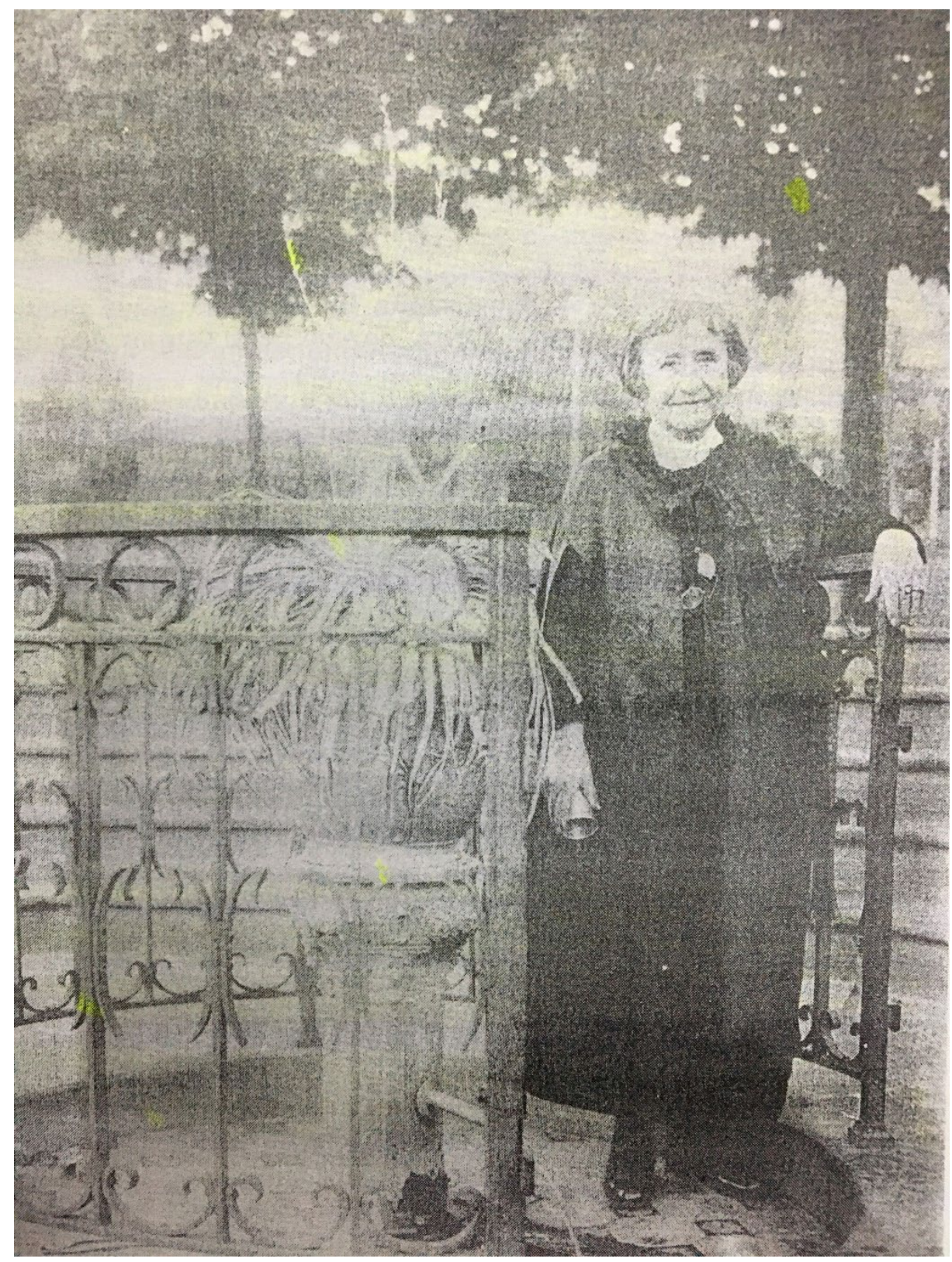

Figura 6 - Dona Maricota, mãe de Isabel, em Caxambu (MG). Fonte: Moraes, [I98I], p. 7 


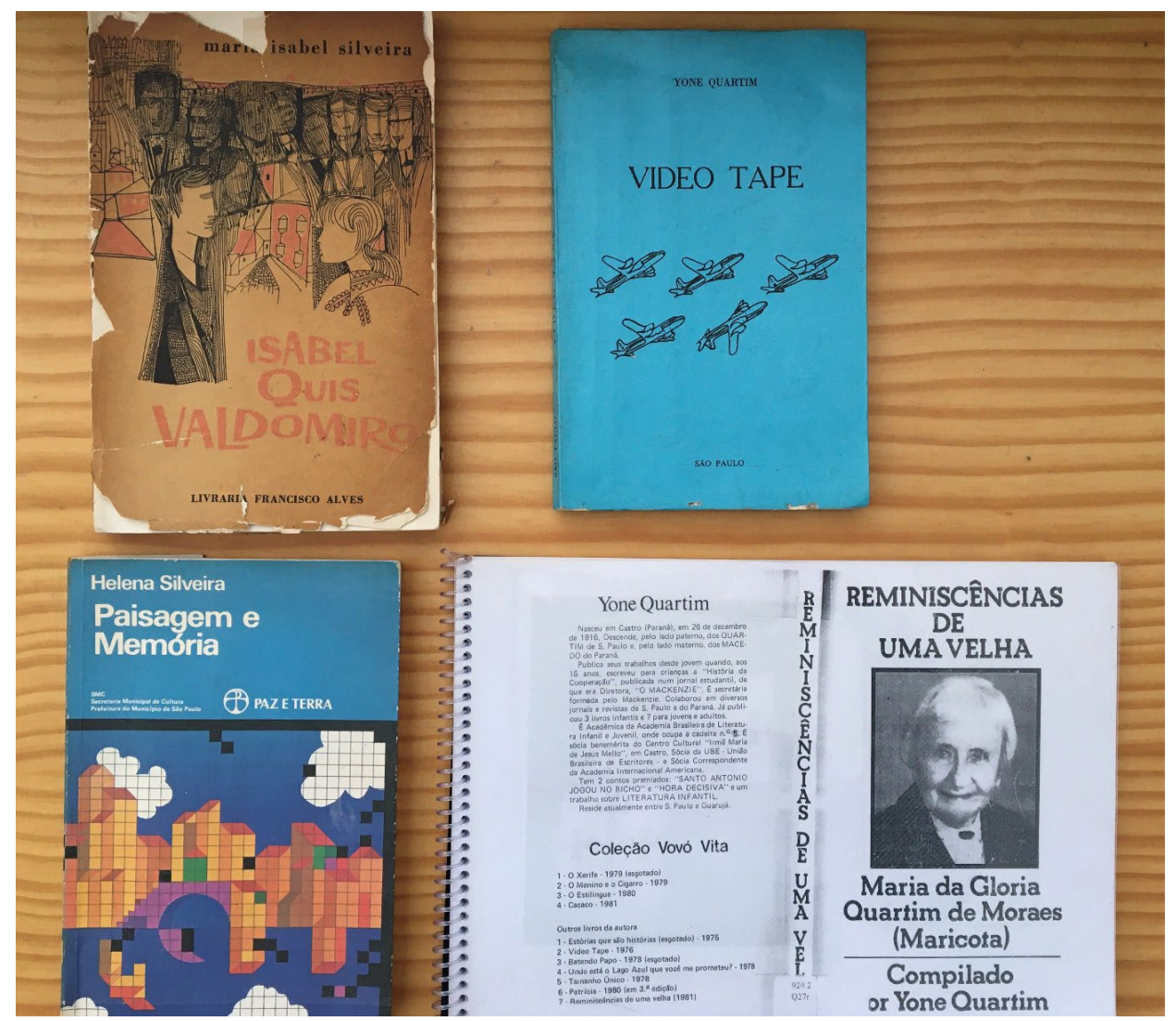

Figura 7- Livros de Isabel, de suas sobrinhas Yone Quartim e Helena Silveira e de sua mãe, D. Maricota

Os cadernos em que D. Maricota contava suas lembranças são conhecidos de toda família e deram origem a Reminiscências de uma velha, compilação póstuma e autofinanciada pela neta, Yone Quartim de Moraes. No cotejo do livro com os originais, evidencia-se o processo transformador de reestruturação e edição de um texto. Yone organiza, seleciona e alinhava as lembranças de infância, mocidade e de parte da vida adulta da avó assumindo a coautoria e suprimindo o viés político contundente e o estilo verborrágico que aparece nos manuscritos. Seus cadernos misturam máximas religiosas, filosóficas e políticas com relato memorialístico. São textos dotados de diferentes tons e intenções, em que se apresenta uma escrita empenhada politicamente, como no trecho a seguir:

Monarquia e República.

Nascida na época monárquica do Brasil, nunca quis aderir à República; isto é (trocar uma coroa por uma carapuça?).

Uma repugnância por tudo que acanalha, como nas repúblicas, desde que elas favorecem paixões incontidas! 
Numa época de progresso e reivindicações científicas, as monarquias tornam-se necessárias, sendo, como são, garantias de estabilidade, tão necessárias à vida das nações. Os povos, munidos de constituições adiantadas, poderiam evoluir com segurança. Como as serpentes das quais tiraram-se os dentes, esses privilegiados engaiolados serviriam de fiadores da paz e da ordem, tão perturbada por esses que com a democracia tudo podem atingir, cheios de soberba e desprovidos de escrúpulos! Indecentes!

Com o desaparecimento das monarquias, desapareceu a cortesia, o respeito, a decência e as boas maneiras!!

Para que vestíbulos? A honra? De que serve? Os republicanos, com a facilidade de tudo atingir, lembram-me burros a escoucearem diante do cocho em que está o milho! Perdendo toda a compostura que dignifica o homem!

A sinceridade e a confiança desapareceram! Sentem-se sempre mal as repúblicas! Em vez de evoluções, fazem revoluções onde inocentes e incautos perdem a vida!

Hoje não se usa pudor filosófico e cível!

Tenho a honra de apresentar o B. R. A. S. I. L. Atual. 
Monarchia e Bepublica.

Mascida ma epucha Mon archica do Brasil, nunca quiz a dherir à Refublica; isto é; (trvear uma corva for uma carafuca.) Uma refugnancia por tudo que aca nalha, como nas Republicas, desde que ellas fa vrecem fraipoes incontidas!

Numa eproca de progressoe eirrindicaveoes seientifieas as Monarchias, tornam-je recessarias, sendo como sam, garantias de estabilida de, tam necessarias a vida das dacoès.

Bs povos, munidos de cons

tituicues a diantadas, poderiam ervluir com seguranca. as quaes tiraram se os dentes, esses 'prevíle gia dos en gaiotádos, serveriam de fia do hes da paye da videm, tam ferturbada por esses que com a Demveracia tu do podem attingir, cheios de voleer ba e despro vidos de es erupulos/. Indecentes?

Com o desapparecim ento das cllo narchias, desafrfarecen a corteria,o

Figura 8 - Registro de um dos diários de D. Maricota. Arquivo IEB/USP, Fundo Valdomiro da Silveira, código de referência VS-CAD-MAR-ooI

232[

revista do Instituto de Estudos Brasileiros · n. 77 • dez. 2020 (p. 220-250) 


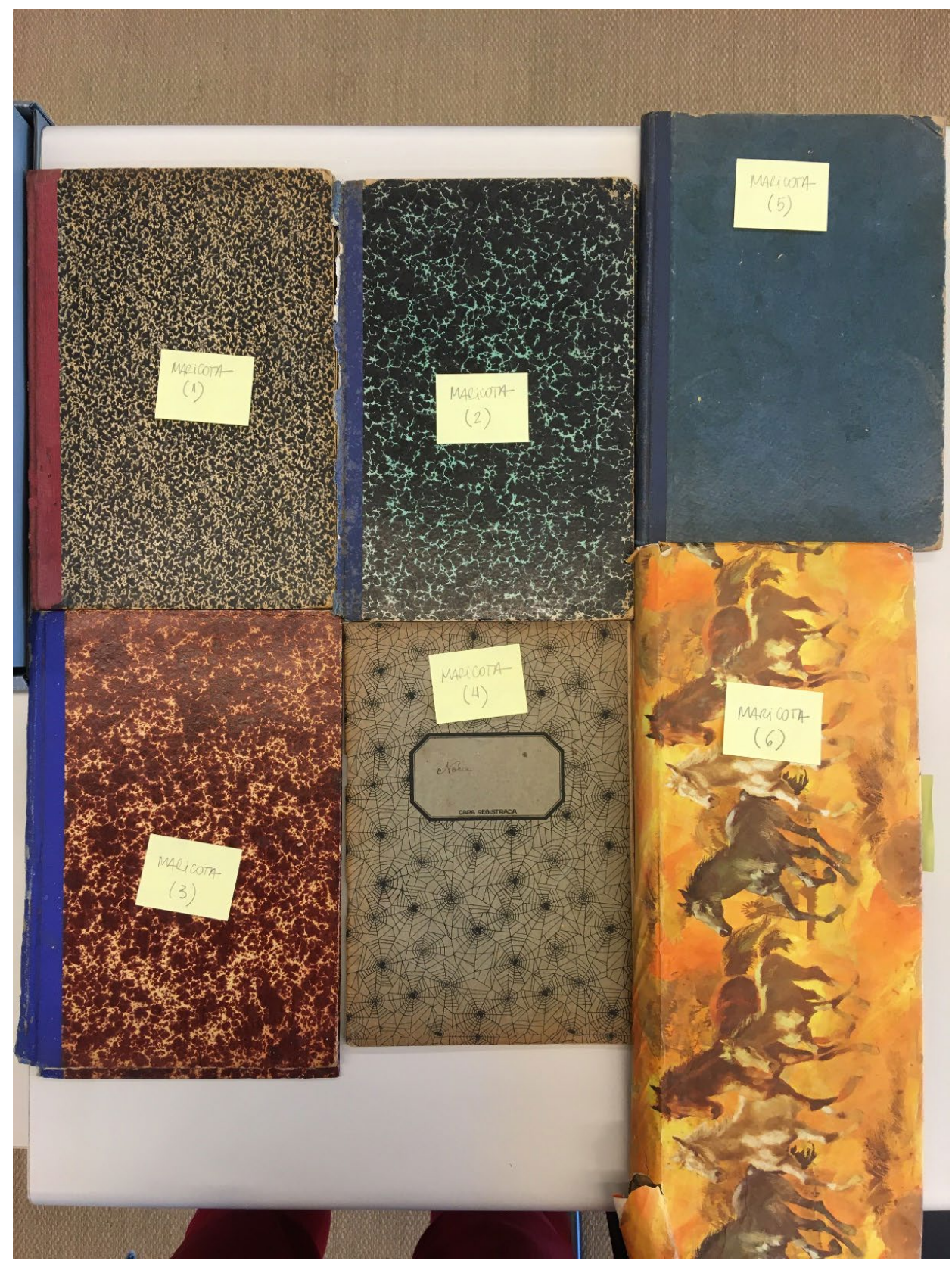

Figura 9-Cadernos de D. Maricota. Arquivo IEB/USP, Fundo Valdomiro da Silveira, códigos de referência VS-CAD-MAR-ooI a VS-CAD-MAR-oo6 


\section{COSTURAR UM DIÁRIO: TRABALHO MANUAL E ARTÍSTICO DA MULHER}

Quarta dos nove filhos de Maria da Glória Quartim de Moraes e João Correa de Moraes, Isabel cresceu em uma família em que a mãe escrevia e o pai era uma figura ausente, que cedo abandonou a casa, deixando a prole aos cuidados da mulher. Tal fato é corroborado pela pouca referência a ele nos diários. Se, por um lado, Isabel não teve formação que lhe propiciasse uma profissão formal, por outro teve rica vivência intelectual e cultural. Lia em italiano e francês. Sendo dona casa, esposa e mãe - identidade feminina condizente com sua época, formação e classe social -, o ato de escrever em um diário se torna um compromisso que ela exerce consigo mesma, com disciplina e constância.

Porém, não é de repente que Isabel e a escrita diarística se encontram; os cadernos indiciam um significativo percurso até o momento em que elege o gênero como favorito. Sendo uma das formas memorialísticas da escrita de si, o diário tem como principal característica a fidelidade ao calendário. As entradas, ou datas da escrita, registram o cotidiano. Fragmentado e em permanente construção, a princípio o diário não é destinado a publicação, sendo um texto sem destinatário aparente. Se, por um lado, as entradas moldam a forma de um diário, por outro, o conteúdo com que se preenche cada entrada não respeita regras. Cada diarista cria seu método e estilo, sendo comum inserir no corpo do diário elementos variados, como citações, fotos, cartas, poemas, narrativas. A criação de códigos para preservar segredos é recorrente entre diaristas, conforme a explicação de Françoise Simonet-Tenant (2004) sobre o diário como um espaço inviolável. E, quanto mais escreve, mais o diarista desenvolve marcas e características próprias.

Os dez diários mais antigos conservados por Isabel formam um primeiro conjunto, preservando a memória de cada um de seus filhos, portanto "diário dos filhos". Esses cadernos se inter-relacionam não apenas cronologicamente (compreendem o período de I908 até I9I9), mas também na materialidade. Quatro deles foram feitos à mão. São folhas de almaço de gramatura espessa, no formato $16 \times 22,5 \mathrm{~cm}$, recortadas (ao meio?) e costuradas com linha vermelha em forma de caderno com Io folhas cada. A irregularidade no corte do papel e o arremate da costura evidenciam as mãos, o trabalho artesanal. $\mathrm{O}$ conjunto aponta para o caráter experimental desse conjunto de cadernos. Não há dados seguros para se afirmar que foram feitos e costurados pela própria Isabel, que gostava de coser e fazia isso com frequência, de acordo com relatos encontrado nos diários. É bem possível que tenha sido ela também a mãe dos cadernos, ou seja, que ela os tenha criado, assim como criou os filhos - o gesto da mãe que cobre todas as instâncias da maternidade, inclusive a da feitura dos cadernos que abrigam as memórias dessas infâncias. 


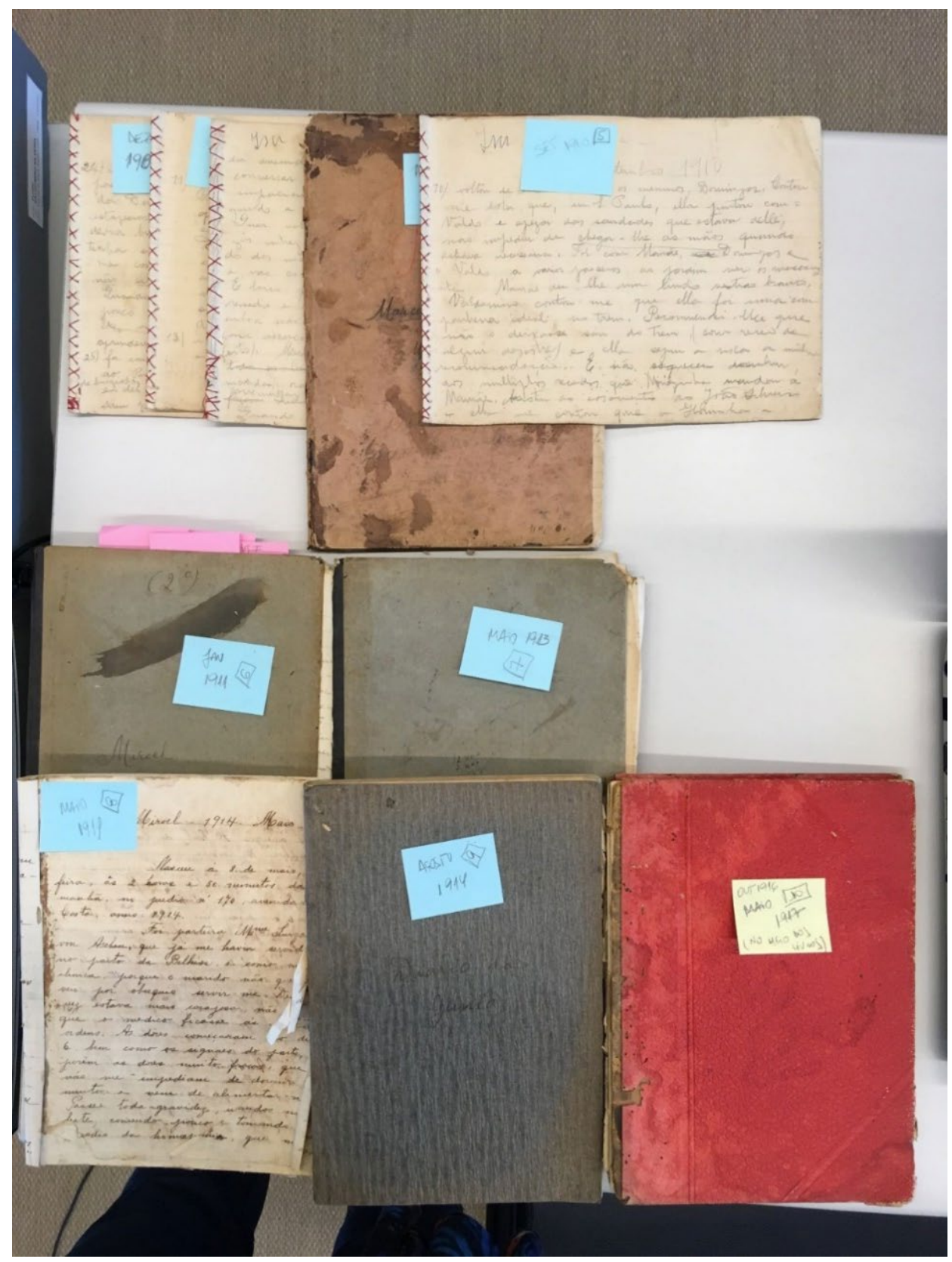

Figura Io - Conjunto “diários dos filhos”. Arquivo IEB/USP, Fundo Valdomiro da Silveira, códigos de referência VS-CAD-MI-ooI a VS-CAD-MI-oIo 


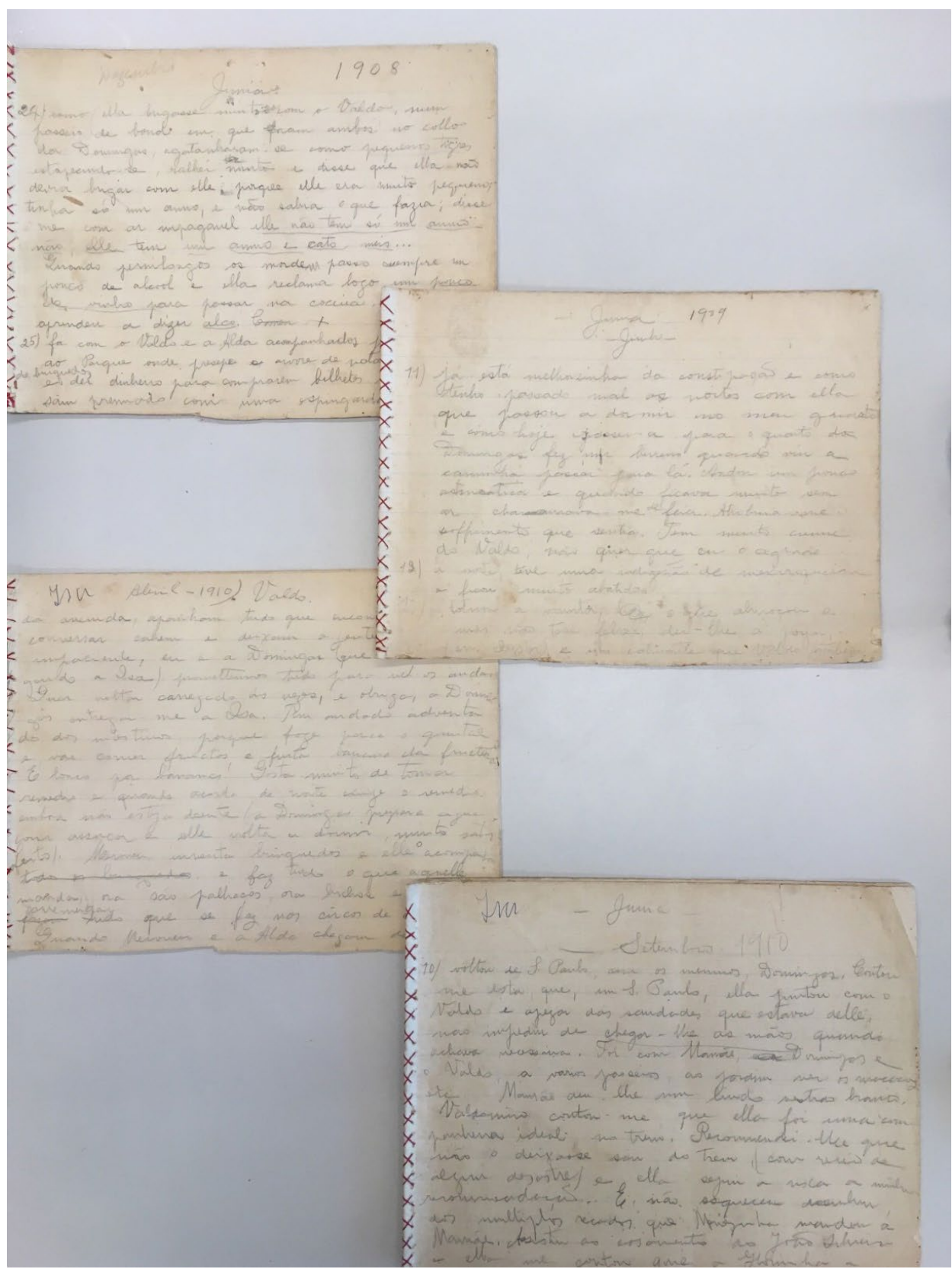

Figura II - Cadernos dos filhos costurados manualmente. Arquivo IEB/USP, Fundo Valdomiro da Silveira, códigos de referência VS-CAD-MI-OoI, VS-CAD-MI-002, VS-CAD-MI-003, VS-CAD-MI-005

Observando a materialidade, o conjunto revela-se como uma espécie de laboratório para a escrita que se firma depois, nos diários que aparecem em I924 e I925. Os "diários dos filhos" apresentam uma escrita instável, como se ela ainda 
não tivesse se apropriado inteiramente da forma. Nota-se a preferência da escrita a lápis. Folheando os diários, algumas marcas se sobressaem: palavras e frases sublinhadas e rasuradas. É instigante pensar que, mesmo escrevendo a lápis, Isabel não faz uso de uma borracha. Qual seria então a justificativa para o uso do lápis? Se, por um lado, pode sugerir descuido e pressa, por outro, demonstra um estar à vontade nesse espaço, a ponto de não querer perder tempo apagando. Segue escrevendo sem interromper, parecendo ser o objetivo principal da prática.

Os "diários dos filhos" remetem a um momento de experimentação em que Isabel se coloca com inteira liberdade diante da folha em branco. Marcados pela irregularidade, Isabel recheia os "diários dos filhos" com muitas narrativas, textos que começam sem data específica. Ela anota o mês, por exemplo, e escreve abaixo um texto corrido em prosa. Alguns saltos temporais às vezes são justificados:

(Infelizmente, por me sentir indisposta e andar sempre passando mal, deixei de tomar notas, justamente na ocasião em que ela esteve mais interessante e cheia de pilhéria, lembro-me de algumas graças que ponho agora e sem lembrar-me das datas.) Só guardei a data em que pôs os dentes que menciono. (II de outubro de I9II, diário de Isa).

Os “diários dos filhos" são preenchidos de toda matéria que pulsa na vida de mãe. Ela descreve as irritabilidades e doenças que sofrem (sarampo, desarranjos intestinais, asma, irritabilidade pela dentição etc.), os tratamentos e remédios, a interação das crianças com os empregados, se estão magras ou gordas e coradas, além das situações cômicas que vivenciam. Ainda na entrada mais antiga (24 de dezembro de I908), nota-se o grifo de Isabel em algumas palavras indicando a fala de Júnia, com 2 anos e meio. Há uma mimetização da fala da criança. Será pensando em um futuro leitor (a própria Júnia, mais velha) que ela faz tais marcações?

Inicialmente, os diários tinham como finalidade abrigar as memórias da primeira infância dos filhos para serem reconhecidas posteriormente. No livro de memórias que publica em I962, Isabel comenta a escrita dos "diários dos filhos" a partir de outro ponto de vista:

Chovesse ou fizesse sol, morta de sono, no meio dos maiores cansaços ou aborrecimentos, não deixei de ir anotando os acontecimentos dia a dia, semana a semana, ano a ano, e por isso eles não perderam seu sabor do momento nem ficaram falseados pela imaginação ou pela saudade. São dados autênticos, os de que me servi para escrever a história que aqui se inicia. (SILVEIRA, I962, p. 8).

O distanciamento temporal ressignifica a finalidade dos diários apontando para um conjunto que serve de base para a escrita memorialística. Nesse caso, os "diários dos filhos” estão de acordo com a proposição crítica de Lejeune (20I5, p. I5), em "O diário: gênese de uma prática”, ao assegurar que o diário não é uma obra em sua finalidade, mas pode abrigar e testemunhar uma obra que nasce simultânea ou posteriormente.

Isabel escreve para realçar os feitos dos filhos pelo aspecto do que pode ser memorável. A escrita se dá pela admiração de mãe zelosa em observar o desenvolvimento 
e amadurecimento da sua prole. Por se orgulhar das crianças que tem, ela pode, quem sabe, se orgulhar da mãe que é:

Fala corretamente, emprega termos, conta que levou o tombo e disse: essa cama é mais perigosa.... (29 de janeiro de I909, diário de Júnia);

Alta noite ferrou uma prosa conosco a propósito de balas e biscoitos. Acorda numa lucidez espantosa. (3I de maio de I9I3, diário de Isa).

A qualidade do que é memorável passa pela esperteza, pela graça dos filhos, pela sensibilidade que demonstram e pela rapidez com que aprendem. Com frequência são anotações que comprovam e aprovam o comportamento dos filhos e que reforçam a visão de mundo que cerca Isabel. Mãe que prezava a cultura, Isabel valorizava o aprendizado da língua francesa e inglesa, assim como desejava ver os filhos adquirindo conhecimentos musicais:

Estou ansiosa que ela aprenda música, pois quero que todos os filhos saibam-na bem. (29 de abril de I9I3, diário de Júnia);

Tratei uma professora de francês de sociedade com Bijou, para falarmos bem o francês e chamo-a e ao Valdo para assistir as lições e irem familiarizando-se com o francês também. (7 de agosto de I9I3, diário de Júnia).

\section{DIÁRIO I: I925 - ANO DO CASAMENTO DA PRIMOGÊNITA E CONSOLIDAÇÃO DA ESCRITA DIARÍSTICA}

É de se perguntar o que teria feito Isabel documentar a si mesma durante tantos anos. O diário é associado, historicamente, a uma forma de escrita feminina:

Por essas características, que poderiam ser vistas inversamente como formas de descaracterização do texto, já que ele pode aparecer enxertado de variadas vozes e modelos discursivos, o diário íntimo foi uma das primeiras formas de manifestação escrita da mulher. Tanto é verdade que o primeiro livro memorialístico escrito por mulher de que se tem notícia no Brasil foi um diário, cuja elaboração teve início em I893, embora sua publicação só tenha ocorrido meio século depois. (VIANA, I995, p. 53).

Essa autora refere-se ao livro Minha vida de menina, de Helena Morley. Talvez tenha sido o apelo ao gênero o que tenha atraído Isabel uma vez que os diários mais antigos são escritos pela mãe. O primeiro diário em que escreve exclusivamente sobre si compreende o período de Io de janeiro até 3I de dezembro de I925. Sobram poucas páginas em branco de um total de 300 ; a diarista deixa de escrever em apenas 29 dos 365 dias desse ano. O Diário I se consolida materialmente como o preferido entre os tipos de caderno feitos de diário: tamanho 24,5 x I7 cm, pautado, lombada de couro, I50 páginas, capa lisa de estilo marmorizado. Nota-se uma moldura em que a escrita se encaixa repetidamente de maneira estável: o ano e o mês são escritos na primeira linha da primeira página centralizados; o número correspondente ao 
dia segue na linha abaixo com um único sinal de parêntese separando-o do dia da semana que vem logo após. A caligrafia de Isabel é bonita e de fácil leitura, sua escrita é gramaticalmente correta e atenta; ela explora a linguagem em todos os aspectos: no vocabulário, no uso da pontuação, marca os estrangeirismos e expressa-se muito bem a ponto de sua escrita revelar uma ética, seus valores e visão de mundo

Quanto ao conteúdo, Isabel inicia as entradas contando a que horas acordou, descreve o tempo: se está calor, frio, venta ("noroestou") ou chove, se nadou bem cedo, como de costume, e quem a acompanhou; o retorno para casa é seguido dos arranjos e arrumações para o almoço; descreve suas ações e os passeios à tarde; se tomou chá e com quem e o jantar em família. À noite, é frequente Isabel registrar passeios como idas ao cinema ou saídas para tomar sorvete. As entradas terminam com o registro das últimas sensações e sentimentos do dia, antes de incluir o horário em que se deita para dormir. 


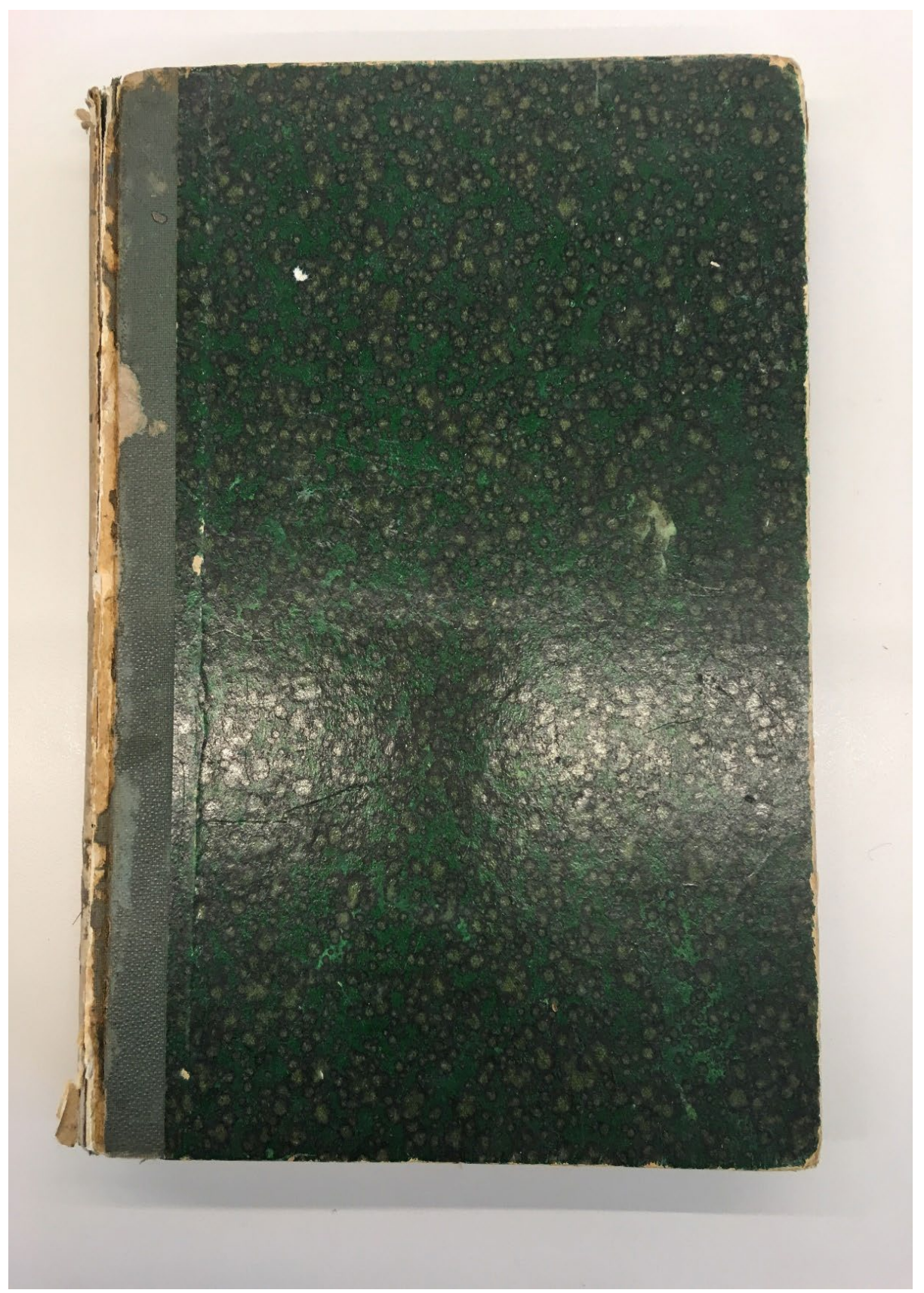

Figura I2 - Diário de I925, com lombada de couro. Arquivo IEB/USP, Fundo Valdomiro da Silveira, código de referência VS-DIA-MI-oI3 
Saneiro-1925.

1) entrei o anno behendo, com todos a' mesa (isto a meia noite) nu vinhs. sspumante itahino sandando entra da de 1925 (III). Comemos cartanhm, hiscontrs, figos, fastas, nozes, amendoas, areellas ete. ete. Estava muito alegre, Ditamo-nos em seguida. Levantamo-nos cedo. Gotme todu a manha en arrumacrés, defois desancei un cama, domindo sm fonco. Almocams a 1 hora, nm - lindo feni que estura delicioso, lubemos vanis suinos doces que - recebenos e outros que amfroma
Comoms costuri has etc.

Costüre un ponco. Mantruse Hbeito viesam nos nes e aqmi estiveran duns hom e tanto, Aquelle len-my a lindn peca "Emburque pura leythern" 'que nos encontin.

of' tride fomm ao bumbo de mar; encontranos va prain enc Glga e Edmudo, tendo este

Figura I3 - Diário de I925. A indicação da data com mês e ano centralizados e dia na primeira linha seguido de parêntese é uma característica da escrita diarística de Isabel. Arquivo IEB/USP, Fundo Valdomiro da Silveira, código de referência VS-DIA-MI-oI3

revista do Instituto de Estudos Brasileiros · n. 77 • dez. 2020 (p. 220-250)

] $24 \mathrm{I}$ 
A pesquisa da historiadora Vânia Carneiro de Carvalho (2008), Gênero e artefato: o sistema doméstico na perspectiva da cultura material - São Paulo, I870-I920, situa o momento de efervescência e de mudanças na vida familiar e urbana da cidade de São Paulo. A economia paulista enriquece com o café, e muitas famílias de fazendeiros mudam-se para a cidade. Criam-se novas práticas de consumo que inauguram um modo de vida burguês. Os diários de Isabel refletem esse contexto em que a crescente urbanização e a industrialização concebem a ideia de modernidade. Um dia com valor positivo e bem vivido para Isabel é um dia com atividades externas, muita ação, encontros e prosa. A ideia de novidade perpassa o momento:

\begin{abstract}
9) sexta. Estudei mais de uma hora de piano de manhã. Calor horrível! Depois do almoço fui para a cama de indisposta. Guaraci almoçou conosco. Tirou retratos das meninas e também delas comigo. Fizemos uma orquestra. Deitei-me cedo, o dia correu sem novidade. (Diário I, 9 de janeiro de I925).
\end{abstract}

(Esqueci-me de fazer o diário de ontem (Ig), em que não houve novidade). Só foi Nenê que trouxe o Álvaro, a chamado telegráfico de Valdomiro, para fazer uma injeção antitetânica, pois ele enterrou um prego no pé. Dr. Odorico veio fazer a injeção. Fomos todos à tarde ao banho de mar, o que encantou o Álvaro, que não queria sair da água. À noite fui com Nenê à casa de Hortênsia, visitar Tia Amélia e voltamos logo.) (Diário I, 20 de janeiro de I925).

Viemos para a estação para pegarmos outro trem para voltarmos. Jantamos no trem e não encontramos novidade. (Diário I, 26 de março de I925).

O ano de I925 é marcado por dois eventos importantes para a família Silveira: o casamento de Júnia, a primogênita, com Amílcar Mendes Gonçalves, em 22 de junho, e a reforma e mudança para a casa onde a família passa a morar definitivamente até a morte de Valdomiro, em I94I. Durante boa parte do primeiro semestre de I925, todos os integrantes da família residem provisoriamente no hotel "Parque", enquanto a casa é reformada, e Isabel claramente é quem coordena os trabalhos. A compra da casa é uma conquista em que ela muito se empenhou para convencer Valdomiro da importância de serem proprietários.

Nota-se o compromisso de Isabel com a sinceridade e a fidelidade a uma realidade. Ela confirma esse pacto quando diz ter se apoiado nos diários para dar origem ao livro, décadas depois. A base de sua escrita diarística é o enraizamento no cotidiano, e isso implica em ligação com os fatos. O diário registra o eu no papel, e aquele que escreve é o primeiro leitor dessa escrita de si. Porém, escrita é discurso, linguagem e representação; se iludirá aquele que não desconfiar da imagem de papel. O estilo regular e constante, inaugurado em I925, ao qual se mantém fiel 40 anos depois, supõe uma figura única e ausente de ambivalências. Os diários de Isabel não se caracterizam pelo registro de confissões, de relatos de conflitos ou angústias. Nos dias em que registra choro, tristeza e aborrecimentos, por exemplo, há sempre uma mudança brusca de tom em seguida ou o ponto-final: 
8) domingo. Estive toda a manhã na frente do hotel tomando ar e conversando com diversos conhecidos.

Valdomiro deixou-me num estado nervoso horrível, passei um dia tão aborrecido (como sempre). Deitei-me um pouco de dia, mas a manha do Paulico não me deixou dormir quase.

Amílcar chegou às II horas, almoçando conosco. À tarde também estive na frente vendo o corso e conversando com D. Bertha Schmit e D. Helena Allen. À noite Júnia cantou ao violão no salão, a pedido das famílias Schmit e Madeira. Deitei-me cedo e chorei como uma louca. Valdomiro foi passear com Julieta e quando voltaram já estava dormindo. (Diário I, 8 de março de I925).

30) segunda. Fomos eu e Júnia com o Amílcar a S. Paulo para cuidar do enxoval e costureiras. Fizemos tudo a contento. Almoçamos com D. Julieta. Voltamos pelo trem das 4 e I5. Sr. Castanho trouxe-nos no seu auto. Veio de prosa conosco e correu tudo bem rápido. VIII.

Deitamo-nos cedo. Chorei muito. (Diário I, 30 de março de I925).

26) sexta. Estive cedo em casa vendo as obras, estudei canto e piano. Recebemos de um cliente umas mexericas. Depois do almoço fui ao Parque visitar Alzirinha Assumpção e agradecer à Mme. Floville as gentilezas. Depois fui à cidade ao escritório, passando antes pelas lojas (para mandarem as contas) e pelo sapateiro da Isa. VIII. Estive com Mme. Alca, que me fez entrar, e Evelina.

À noite não saí. A Isa, Valdo, Belkiss e Miroel foram com presentes (vasilha de metal para pós de arroz, pós de arroz e pluma, além de um vidro de perfume lilás) visitar a Maria. Dia lindo! Valdo deu uma caixa de bombons. Nenezinha e uma filha do Dr. Reis (hóspede) vieram tratar de figurinos para escolher o modelo do vestido de casamento. Veio o moço da casa Pedro dos Santos, para encaixotar os presentes da Júnia. Comecei a ler o livro que dei a Valdomiro. Chorei um pouco antes de dormir. (Diário I, 26 de junho de I925).

Exemplos como esses são recorrentes. Por que ela teria chorado? Quais são as contrariedades que acometem a vida de Isabel? Seu estilo de escrita não se caracteriza pelo sentimentalismo, mas por autodisciplina e controle. 


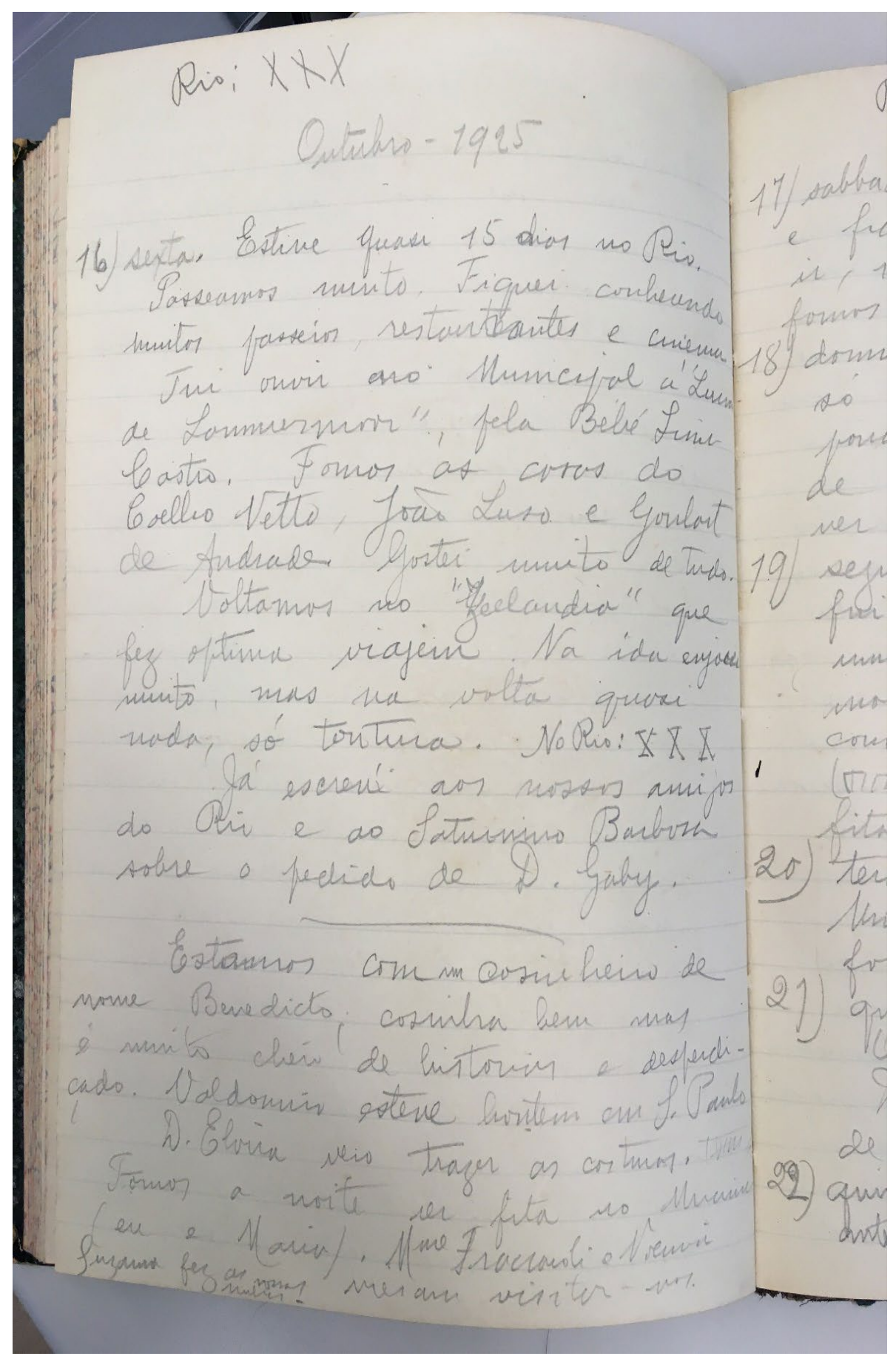

Figura I4 - Diário de I925. Utilização de números romanos para manter privacidade. Arquivo IEB/USP, Fundo Valdomiro da Silveira, código de referência VS-DIA-MI-oI3 


$$
\text { X. } 8-7-25
$$

apois do thinum prosume for wote e estivermh de potio connto mostrand-lles a iens cosp wore.

el 6 segunda. Tii cedo ar Monte-fenate concontrer lá a fumilui Reis (da penta) \$Bife ontrar furni hi (Lascaléa).

Depoin do almovo tui con \& Neginhu a cilove fun nemor sar contar (amprei va lojie tzul \$19 metrin de sedr lavarelf: Fow

- \$jao bolil (vor). Ao chejar un can

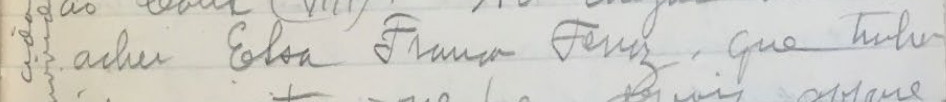

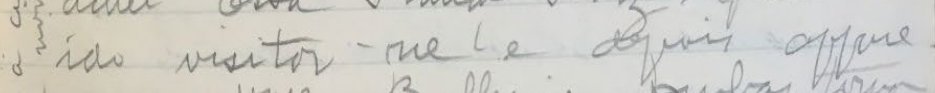
\$en Itwe Ballesine poubas low que 18 rom chí comigi

mes Nas sahi a viti, Nei-

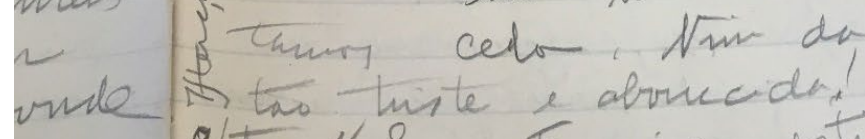

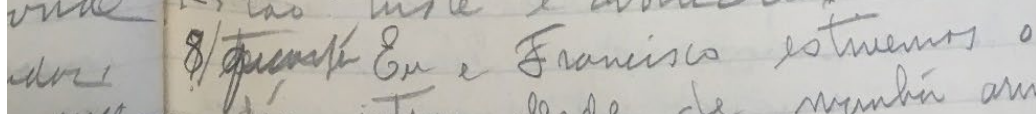
rete- dia inters desde de nunbín arrmona juina do movén variendo e lanenos a

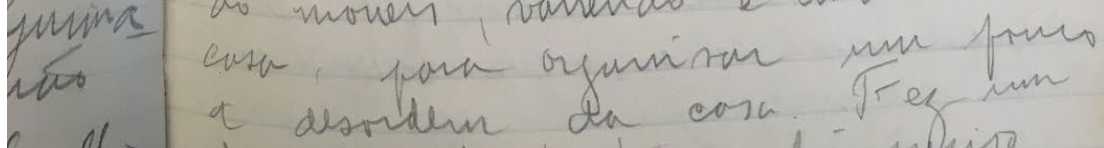
bullo dia lindo! \& torde for peiro

Figura I5 - Diário de I925. Isabel usa um código próprio, que recebe variações, combinando números romanos e datas. Arquivo IEB/USP, Fundo Valdomiro da Silveira, código de referência VS-DIA-MI-oI3

revista do Instituto de Estudos Brasileiros · n. 77 • dez. 2020 (p. 220-250)

] 245 
- Hepoir as com nugar

- escriar in 3 anno vitara do Aberto vero anfidenvin bovir mher grue pore

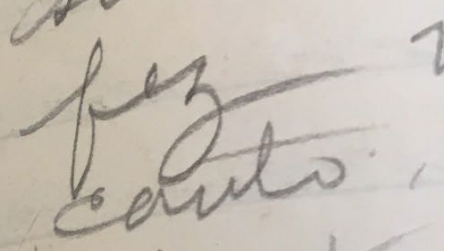
taro (vilife) - e defrur ln jrun an mons

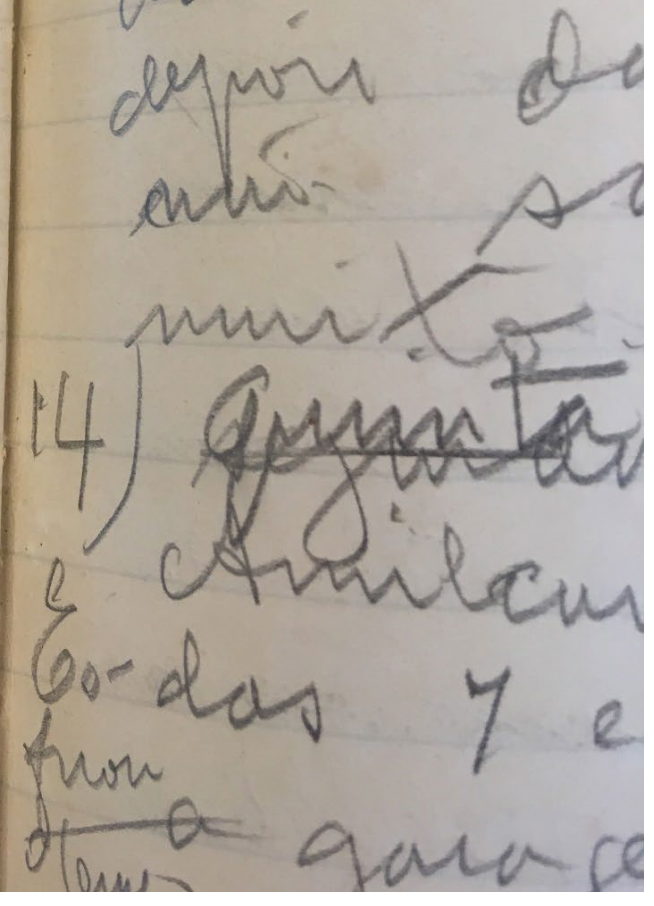

Figura 16 - Diário de I925. O uso de alguns códigos, por exemplo, "VIII duplo", é recorrente na escrita de Isabel. Arquivo IEB/USP, Fundo Valdomiro da Silveira, código de referência VS-DIA-MI-oI3

246[

revista do Instituto de Estudos Brasileiros · n. 77 • dez. 2020 (p. 220-250) 
Em seu estudo sobre a ideia de privacidade na experiência burguesa, Peter Gay (I999) nota que os motivos que levam uma pessoa a escrever sobre si variam, e com eles o grau de introspecção também. Como existiram diaristas que desejavam preservar o passado, outros valeram-se do relato de si em sua função terapêutica, outros escreviam regularmente como modo de combater a solidão ou o isolamento. O mais importante é não perder de vista as lacunas e os silêncios de um diário:

Na verdade, muitos diários são eloquentes no que omitem, na medida em que registram sucintamente transações comerciais, a rotina cotidiana de uma fazenda, as atividades domésticas, e pouco mais. Um diário incomum, em que a dona de casa protesta contra a escravidão doméstica e seu pouco cooperativo senhor e mestre, parece um raio de luz singular, permitindo entrever de modo excepcionalmente informativo ressentimentos que devem ter sido endêmicos, mas que a maioria das mulheres guardavam fora da vista e mesmo da consciência. (GAY, I999, p. 364-365).

É ingênuo ler os diários de Isabel desejando conhecer suas camadas mais profundas. Seu estilo é marcado por uma autodisciplina em função de recato, decoro e controle. Nota-se discrição ao ocultar emoções intensas. As mudanças bruscas que afastam o leitor dos motivos de suas tristezas e aborrecimentos apontam para a reserva esperada de uma mulher de sua classe. Quando quer registrar e simultaneamente esconder, Isabel usa um código próprio composto da combinação de números romanos (X, V, VIII) e datas que recebe variações, como "VIII duplo", por exemplo. Os diários de Isabel apresentam uma cultura que respeita a vida privada nesse conflito de forças entre a medida da transparência e a do grau de exposição.

O vertiginoso crescimento econômico vivido por São Paulo na virada do século XIX para o XX propagava o discurso do progresso no Brasil republicano. As transformações afetavam a vida privada, e nesse contexto encontramos mulheres que excepcionalmente passam a narrar a si próprias, como Maria Isabel: “Minha vida não é nada', diz a maioria das mulheres. Para que falar dela? A não ser para evocar os homens, mais ou menos importantes, que conheceram, acompanharam ou com quem conviveram" (PERROT, 20I7, p. 28). Se os diários examinados apresentam uma escrita pouco íntima, por outro lado se revelam muito pessoais e marcam um lugar de construção da memória. Maria Isabel afirma o eu, e graças a sua escrita ouvimos sua voz culta em relação consigo mesma. A ela convinha calar emoções, esperanças e sofrimentos uma vez que a exposição seria vista como indelicada e fruto de indiscrição.

A escrita de Maria Isabel Silveira insere a presença, frequentemente apagada, dos relatos das mulheres e corrobora a construção da memória feminina, historicamente relegada à insignificância. O percurso exposto a partir de seus diários mais antigos apresenta, em um primeiro momento, uma escrita motivada pela identidade materna que se desdobra mais tarde e se consolida na escrita de si. Quando os filhos crescem e se tornam independentes, a mãe orgulhosa dá lugar à mulher que volta o olhar para contar sua vida. A escrita íntima de Isabel, se por um lado não é reveladora de intensos desejos, por outro, mostra-se atenta em relação ao recato com que a nova mulher burguesa deveria, a seu ver, tratar a privacidade. Os diários rompem com 
o silêncio, mas abafam o choro e iluminam as ambiguidades e ambivalências de mulheres presas a imagens e condutas.

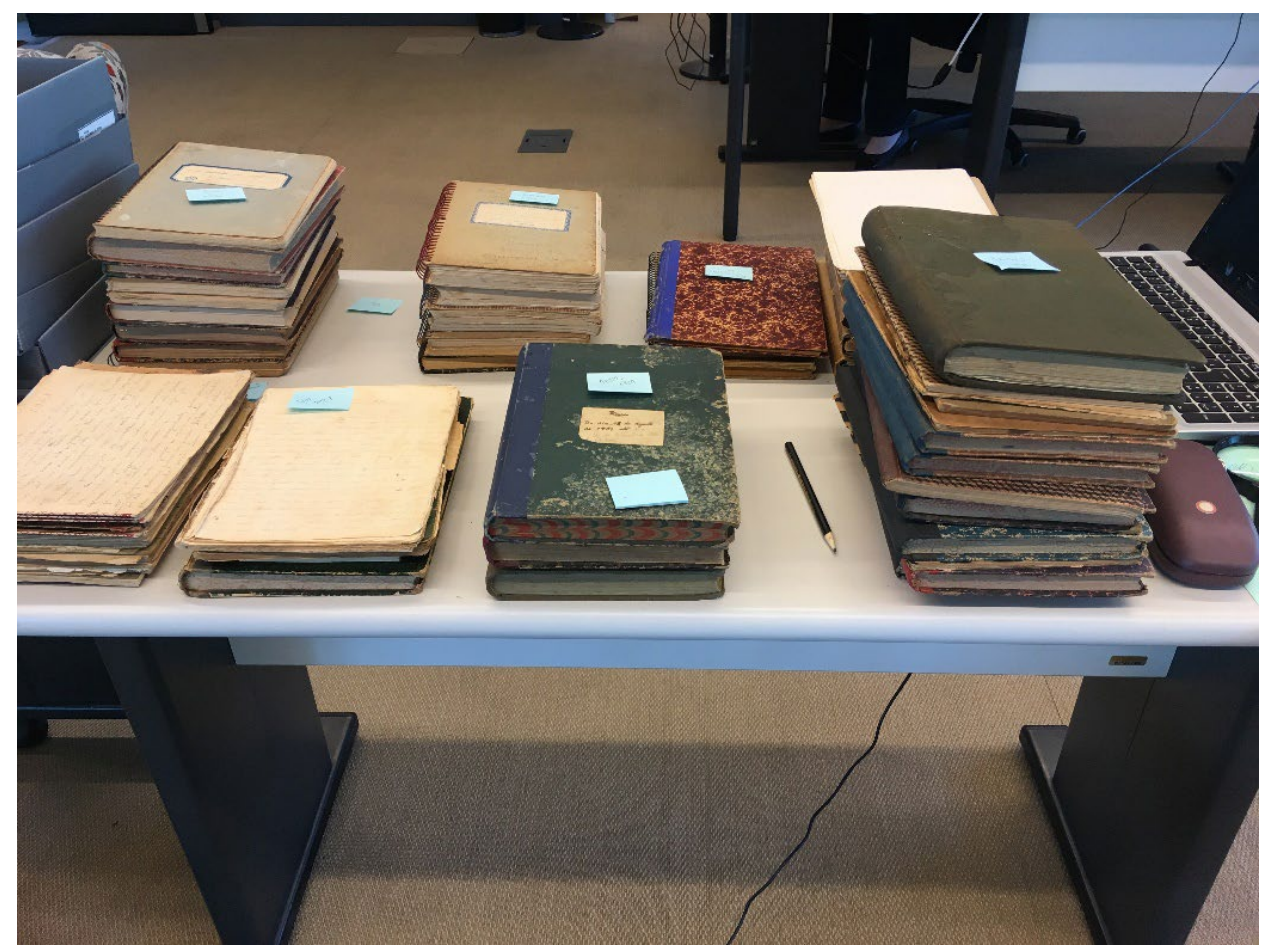

Figura I7 - Todos os cadernos de Maria Isabel que se encontram no Arquivo IEB/USP, Fundo Valdomiro Silveira 


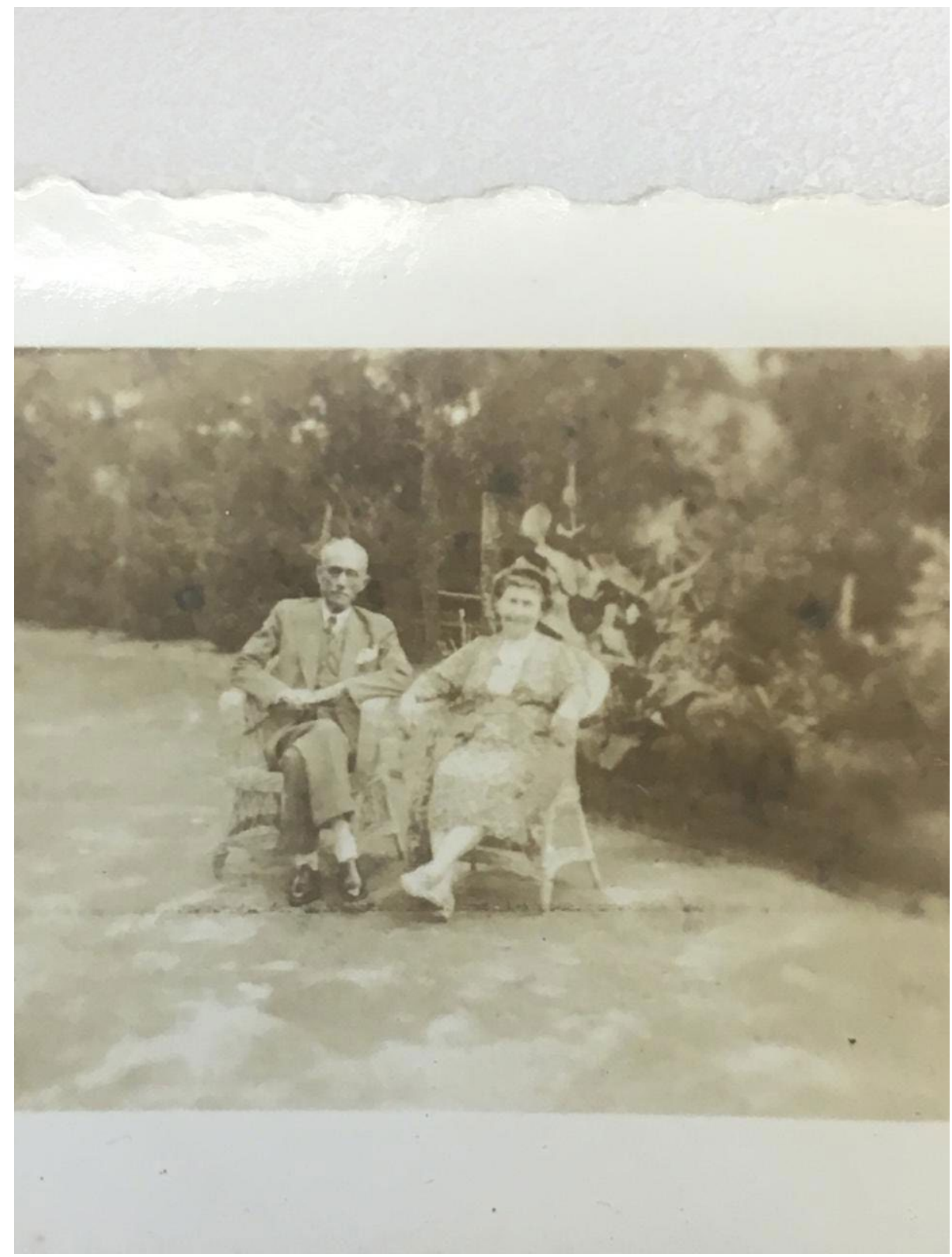

Figura I8 - Isabel e Valdomiro. Arquivo IEB/USP, Fundo Valdomiro da Silveira, código de referência VS-F-005 
MARIANA DINIZ MENDES é mestranda em Literatura Brasileira com bolsa de auxílio à pesquisa (Capes) no Programa de Pós-Graduação em Literatura Brasileira da Faculdade de Filosofia, Letras e Ciências Humanas da Universidade de São Paulo (FFLCH/USP) e integrante do Conselho de Curadores do Prêmio Jabuti.

mariana.mendes@usp.br

https://orcid.org/o0oo-0003-0796-2627

\section{REFERÊNCIAS}

BLANCHOT, Maurice. O livro por vir. Trad. Leyla Perrone-Moisés. 2. ed. São Paulo: Martins Fontes, 2013.

CARVALHO, Vânia Carneiro de. Gênero e artefato: o sistema doméstico na perspectiva da cultura material - São Paulo, I870-I920. São Paulo: Edusp, 2008.

COMTE-SPONVILLE , André. Bom dia, angústia!. Tradução de Maria Ermantina Galvão G. Pereira. São Paulo: Martins Fontes, I997.

GAY, Peter. O coração desvelado: a experiência burguesa da rainha Vitória a Freud. Tradução: Sérgio Bath. São Paulo: Companhia das Letras, 1999. p.364-365.

LACERDA, Lilian de. Álbum de família: memórias de vida, histórias de leitoras. São Paulo: Editora Unesp, 2003.

LEJEUNE, Philippe. O diário: gênese de uma prática. In: GUTFREIND, Cristiane Freitas (org.). Narrar o biográfico. Tradução: Vanise Dresch. Porto Alegre: Editora Sulina, 2015.

MORAES, Maria da Glória Quartim de. Reminiscências de uma velha. Compilado por Yone Quartim. s. l., s. n. [I98I]. 2I9 p.

PERROT, Michelle. Minha história das mulheres. Tradução: Angela M. S. Côrrea. São Paulo: Contexto, $20 I 7$. SILVEIRA, Maria Isabel. Isabel quis Valdomiro: memórias. São Paulo: Francisco Alves, I962.

SIMIONI, Ana Paula Cavalcanti; ELEUTÉRIO, Maria de Lourdes. Mulheres, arquivos e memórias. Apresentação do Dossiê. Revista do Instituto de Estudos Brasileiros, Brasil, n. 7I, p. I9-27, dez. 20I8. https:// doi.org/Io.II606/issn.23I6-90IX.voi7IpI9-27.

SIMONET-TENANT, Françoise. Le journal intime: genre littéraire et écriture ordinaire. Paris: Téraèdre, 2004 .

VIANA, Maria José Motta. Do sótão à vitrine: memórias de mulheres. Belo Horizonte: Editora UFMG/ Faculdade de Letras da UFMG, I995. 